\title{
Supplemental irrigation using brackish water on maize in tropical semi-arid regions of
}

\section{Brazil: yield and economic analysis}

Eduardo Santos Cavalcante ${ }^{1 *} \oplus$, Claudivan Feitosa de Lacerda1®${ }^{1}$, Raimundo Nonato Távora Costa ${ }^{\circledR}$, Hans Raj Gheyi ${ }^{2 \oplus}$, Luciana Luzia Pinho $^{1 \odot}$, Francisco Mardones Sérvulo Bezerra ${ }^{\circledR}$, Adriana Cruz de Oliveira ${ }^{1}$, Juvenaldo Florentino Canjá1@

'Universidade Federal do Ceará/Centro de Ciências Agrárias - Depto. de Engenharia Agrícola, Av. Mister Hull, 2977 60356-001 - Fortaleza, CE - Brasil.

2Universidade Federal do Recôncavo da Bahia - Campus Universitário de Cruz das Almas - Núcleo de Engenharia de Água e Solo, Rua Rui Barbosa, 710 - 44380-000 - Cruz das Almas, BA - Brasil.

*Corresponding author <educavalcanteufc@gmail.com>

Edited by: Mohammad Valipour

Received May 31, 2020

Accepted September 26, 2020
ABSTRACT: Supplemental irrigation during dry spells could reduce maize yield losses in tropical semi-arid regions, notably in small farms. However, good quality water reserves are not sufficient to meet the demands of farming communities. Consequently, our objective was to evaluate the productivity and profitability of maize under different simulated rainfall scenarios, with and without supplemental irrigation (SI) with brackish water. The field experiments were carried out during the cropping seasons of 2018 and 2019 on Ultisol. The experiment followed a randomized block design in the split-plot scheme with four replicates. The plots were formed by simulating the water supply in the soil corresponding to four water scenarios (rainy, normal, drought and severe drought), and the sub-plots with or without SI with brackish water (Electrical conductivity of $4.5 \mathrm{dS} \mathrm{m}^{-1}$ ). Mean yields of green maize ears were 13,083, 11,532, 10,358 and $9,609 \mathrm{~kg} \mathrm{ha}^{-1}$ for rainy, normal, drought and severe drought scenarios, as supplemented with brackish water. For the same treatments without SI the values were 11,394, 7,896, 3,913 and $1,374 \mathrm{~kg} \mathrm{ha}^{-1}$, respectively. Data on farmer's income showed that under normal, drought and severe drought supplementation with brackish water becomes economically advantageous from 0.9, 1.0 and 2.4 ha, respectively, while maize cultivation without $\mathrm{SI}$ is not advantageous under the last two scenarios. For severe drought conditions, however, SI using brackish water reduced commercial yield by $27 \%$ with negative effects on the farmers' profitability. In this case, it is necessary to use water with either lower salinity or select salt tolerant crops.

Keywords: rainfed farming, salinity, supplementary irrigation, biosaline agriculture

\section{Introduction}

Rainfed farming predominates in most of the world, and represents approximately $80 \%$ of the entire cultivated area (FAO, 2017). In Brazil, rainfed farming occupies 69.9 million hectares, approximately $92 \%$ of the total cultivated area, and accounts for $60 \%$ of the gross value of production in the country. In the semi-arid region of Brazil there is also a predominance of rainfed agriculture, but the contribution to the gross value of production is much lower. In this region, the frequent droughts and the irregular distribution of rainfall during the rainy season make the enterprises unfeasible due to drastic reductions in crop yield under rainfed conditions (Menezes et al., 2010; Marengo et al., 2017; Zaninelli et al., 2019).

Drought is a major threat worldwide to crop production. It is part of the variability in the natural climate in the northeastern region of Brazil, and according to climate change projections, it is likely to continue and intensify in the future (Marengo et al., 2017). However, a number of studies show that supplemental irrigation could reduce crop yield losses in dryland areas, particularly in semi-arid regions (Chauhan et al., 2008; Oster and Grattan, 2002). However, this is hampered by the scarcity of low-salinity water reserves, which have been insufficient to meet the demands of farming communities. In this context, the use of marginal-quality waters, including brackish and wastewater, may be an alternative for certain production activities of biosaline agriculture in semi-arid regions (Hamdy et al., 2005; Terceiro Neto et al., 2013).

The occurrence of brackish water sources is common in the Brazilian semi-arid region, predominantly with electrical conductivity between 1.5 and $6.0 \mathrm{dS} \mathrm{m}^{-1}$, low sulfate concentrations and high concentrations of chloride and sodium (Silva Júnior et al., 1999). Continuous use of brackish waters in irrigation causes accumulation of salts in the soil (Beltrán, 1999; Pessoa et al., 2019), resulting in the inhibition of physiological processes and reduction in maize yield (Barbosa et al., 2012; Muuns and Tester, 2008). However, studies conducted on certain annual crops have shown that irrigation with saline water for short periods does not cause significant damage to yield and the negative impacts on soil are minimal (Barbosa et al., 2012; Kang et al., 2010; Murtaza et al., 2006; Neves et al., 2015; Terceiro Neto et al., 2013).

There is a need for more detailed studies on the reality of the Brazilian semi-arid region, relating the different problems that permeate this climate and seeking ways that promote better coexistence with water scarcity conditions. Thus, the hypothesis of our work is that the use of brackish water in supplemental irrigation can reduce the negative impacts of the water shortage on productivity and enhance economic profitability of maize cultivation under the conditions of the Brazilian semi-arid region. Therefore, the objective of this study 
was to evaluate the yield and profitability of maize cultivation, under different water scenarios and dry spell intensities, simulating the application of water in the soil based on a historical series of precipitation data for the rainfed farming period in the Brazilian semi-arid region, with and without supplemental irrigation with brackish water.

\section{Materials and Methods}

The experiment was conducted during the dry season in 2018 and 2019, between Aug and Dec in Fortaleza (374' S, 38 $58^{\prime} \mathrm{W}$, altitude of $\left.19 \mathrm{~m}\right)$, Ceará, Brazil. During the experimental period, the mean, minimum and maximum temperatures were, respectively, 27.6, 22.7 and $30.6{ }^{\circ} \mathrm{C}$ for 2018 and $27.2,25.3$ and $30.1^{\circ} \mathrm{C}$ for 2019. The soil in this area is classified as Ultisol, with sandy loam texture in the A horizon (82.9\% sand, $6.4 \%$ silt, and $10.7 \%$ clay).

The experiment followed a randomized block design in a split-plot scheme with four replicates. The plots were formed by the simulation of soil water application corresponding to four water scenarios rainy, normal, drought and severe drought (simulations based on a historical series of precipitation data for the rainfed farming period in the Brazilian semi-arid region), and the subplots with or without supplemental irrigation with brackish water (electrical conductivity $\mathrm{ECW}=4.5$ $\left.\mathrm{dS} \mathrm{m}^{-1}\right)$. Each plot consisted of six planting rows, and each subplot had three 10 -m-long planting rows using a spacing of $0.80 \times 0.20 \mathrm{~m}$.
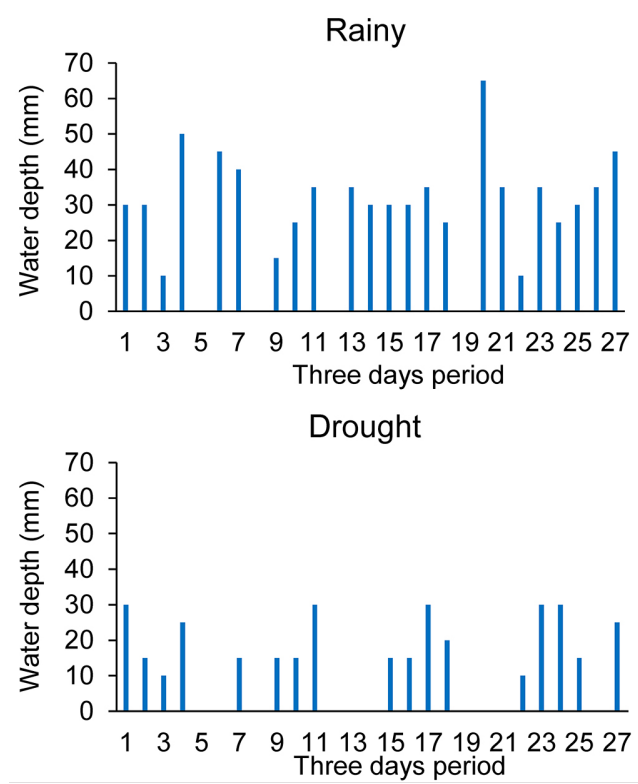

The water scenarios were defined using precipitation and dry spell patterns, based on a 30-year historical series (Figure 1) provided by the Foundation for Meteorology and Water Resources of Ceará (Funceme) for the Curu Valley region, Ceará (semi-arid) for the rainfed farming period in the region (Feb to May). According to these data, the following rainfall totals for these four months were $900,500,390$ and $260 \mathrm{~mm}$, respectively, for the rainy, normal, drought and severe drought scenarios (Figure 1).

The occurrence of dry spells was represented by at least five consecutive days without rainfall, and the duration and quantity were defined by the distribution of rainfall from the historical series. Figure 2 presents both the water depths applied to the different water scenarios from planting to harvesting (80-82 days), and the occurrence of dry spells over time. Total water depths applied throughout the maize crop cycle under

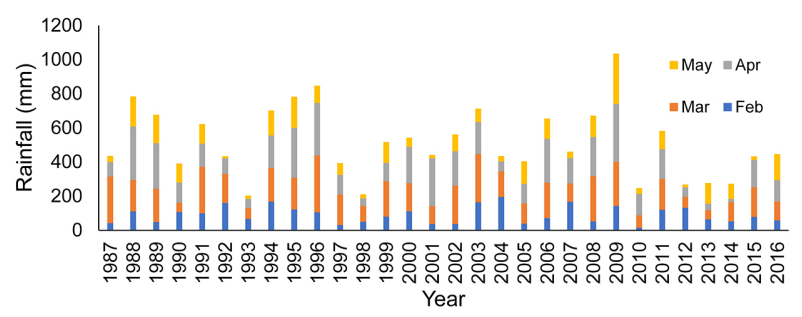

Figure 1 - Thirty-year rainfall historical series (1987 to 2016) for the Curu Valley region, Ceará, Brazil, during the months of the wet season (Feb to May). Data were provided by Foundation for Meteorology and Water Resources of Ceará (Funceme).
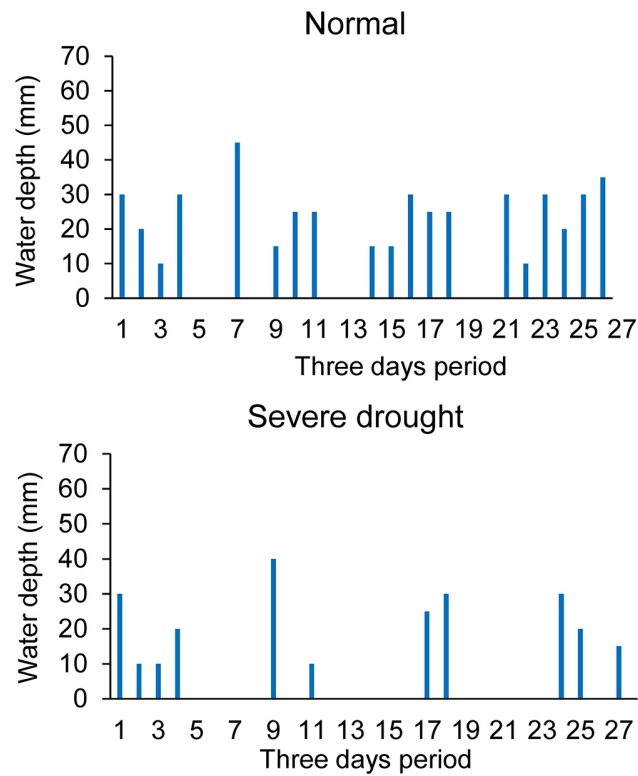

Figure 2 - Water depths applied at three day intervals throughout maize crop cycle for different simulated water scenarios (without supplemental irrigation). The data are the means of the two crop cycles which were very similar. The values of rainfall recorded in 2018 (13.7 mm) and 2019 $(36.8 \mathrm{~mm})$ were included as part of the total for each scenario. Total water depths of supplemental irrigation with brackish water applied during the dry spells were 51, 102, 172 and $260 \mathrm{~mm}$, respectively for the rainy, normal, drought and severe drought scenarios. 
the different simulated water scenarios, without and with supplemental irrigation with brackish water were, respectively: 745 and $796 \mathrm{~mm}$ (rainy), 465 and $567 \mathrm{~mm}$ (normal), 345 and $517 \mathrm{~mm}$ (drought), 240 and $500 \mathrm{~mm}$ (severe drought). The data were the means of the two crop cycles which were very similar.

The cultivation of maize (Zea mays L.) BRS 2022 hybrid was carried out in two years: 31 Aug to 21 Nov 2018, and 28 Sept to 18 Dec, 2019. Sowing in each year was undertaken after applying water to a depth of 30 $\mathrm{mm}$, simulating a soil moisture condition normally encountered by farmers in the northeast region of Brazil at the time of planting. Ninety days before the sowing in 2018, plowing and harrowing operations were carried out in the experimental area, and limestone was incorporated into the soil at a dose of $2.0 \mathrm{Mg} \mathrm{ha}^{-1}$ to correct its acidity (initial $\mathrm{pH}=5.0$ ). Prior to the sowing in 2019, plowing and harrowing were performed and gypsum was applied at a dose of $1.0 \mathrm{Mg} \mathrm{ha}^{-1}$, in order to prevent possible problems of soil sodicity (exchangeable sodium percentage).

Irrigation was carried out with a drip system, using drip tapes consisting of a flexible polyethylene material, with pressure-compensating emitters, with a flow rate of $2.7 \mathrm{~L} \mathrm{~h}^{-1}$ and spacing between emitters measuring 0.4 $\mathrm{m}$. In periods without dry spells, irrigations were carried out with low-salinity water $\left(\mathrm{ECw}=0.8 \mathrm{dS} \mathrm{m}^{-1}\right)$, seeking to apply water volumes according to the historical series of precipitation data. In the first and second cycles, the rainfall totals recorded in a rain gauge were 13.7 and 36.8 $\mathrm{mm}$, respectively, and these values were considered as part of the total for each treatment. Supplementation with brackish water $\left(\mathrm{ECW}=4.5 \mathrm{dS} \mathrm{m}^{-1}\right)$ was performed based on the values of crop evapotranspiration (Allen et al., 1998), estimated during the dry spells, adding a leaching fraction of $20 \%$ in each irrigation event. The total depths of brackish water applied in the supplementation were 51, 102, 172 and $260 \mathrm{~mm}$, respectively for the rainy, normal, drought and severe drought scenarios. Brackish water was prepared with the salts $\mathrm{NaCl}, \mathrm{CaCl}_{2} \cdot 2 \mathrm{H}_{2} \mathrm{O}$ and $\mathrm{MgCl}_{2} \cdot 6 \mathrm{H}_{2} \mathrm{O}$, in the equivalent ratio of $7: 2: 1$, respectively, simulating a water source similar to the brackish waters found in the northeast region of Brazil, and the electrical conductivity of $4.5 \mathrm{dS} \mathrm{m} \mathrm{m}^{-1}$ is commonly found in well waters of the Brazilian semi-arid region (Silva Júnior et al., 1999; Barbosa et al., 2012).

Fertilizations with nitrogen $\left(70 \mathrm{~kg} \mathrm{ha}^{-1}\right)$, phosphorus (40 kg ha-1 of $\left.\mathrm{P}_{2} \mathrm{O}_{5}\right)$ and potassium $\left(20 \mathrm{~kg} \mathrm{ha}^{-1}\right.$ of $\mathrm{K}_{2} \mathrm{O}$ ) were undertaken in line with the fertilizer recommendations for maize under rainfed farming in the state of Ceará, using the following fertilizers: urea, single superphosphate and potassium chloride. The phosphorus dose was added as basal application, the potassium dose was split into two equal portions (one at sowing and the other as topdressing), and the nitrogen dose was split into three equal parts (one at sowing and two as top-dressing). The fertilizers were applied manually and the rates were the same for all treatments.
Harvesting was at 82 and 80 days after sowing, for the first and second cycles, respectively, by randomly collecting 15 plants from the central row of each subplot. Green maize ears were weighed and the yield was estimated taking into account the fresh biomass of the ears with straw, planting density and final stand. The percentage of stand reduction was estimated by relating the total number of plants at the end and at the beginning of each cultivation cycle. The results of the total yield of green ears were subjected to analysis of variance and the means were compared by Tukey test at a 0.05 probability level, using the statistical software program SISVAR version 5.6.

Economic analysis was performed using current values (Apr-May 2020) to estimate gross revenue and costs (fixed, variable and equipment depreciation), expressed in United States Dollars (USD). The current exchange rate of 5.28 Reals $=1.0$ USD was used to convert Brazilian currency (Reals) to USD. Yield data were used to estimate gross revenue, using the price of green maize paid to the farmer by the State Supply Center (Ceasa-CE), equal to 0.23 USD per kilogram, referring to the current mean price during the rainy season. Gross revenue was determined using only the commercial yield of green ears, i.e., ears with weight equal to or greater than $250 \mathrm{~g}$, in accordance with the minimum values of ears brought to market at Ceasa - CE. The fixed costs relative to 1.0 ha for all water scenarios with or without supplementation are shown in Table 1. The total value of the fixed cost was divided over ten years, because the farmer has the option to finance the materials during this period.

As regards variable costs (Table 2), the electricity charges varied according to the water depth applied in the treatments with supplementation and was equal to zero in treatments without supplemental irrigation. The depreciation value of the equipment was calculated by dividing the need for investment (well and irrigation system) by the useful life which was estimated at 10 years. The depreciation value obtained was 27.84 USD for water scenarios with supplementation, and there were no depreciation costs for the water scenarios without supplementation.

Seeking to get as close as possible to the reality faced by the farmer, this study took into account the following: the costs were financed by Banco do Nordeste do Brasil, using the investment credit line called "Pronaf Mais Alimentos", simulating a 10 year contract, at an

Table 1 - Fixed costs relative to 1.0 ha for the cultivation of maize in each cycle.

\begin{tabular}{lcc}
\hline Types of costs & $\begin{array}{c}\text { With supplemental } \\
\text { irrigation }\end{array}$ & $\begin{array}{c}\text { Without supplemental } \\
\text { irrigation }\end{array}$ \\
\cline { 2 - 3 } Well (15 m deep) & 890.15 & 0.0 \\
Drip irrigation system & $1,893.94$ & 0.0 \\
\hline Total & $2,784.09$ & 0.0 \\
\hline Financing share ${ }^{1}$ (fixed cost) & 278.41 & 0.0
\end{tabular}

${ }^{1}$ Considering financing period of 10 years. 
Table 2 - Variable costs relative to 1.0 ha for cultivation of maize in each cycle, excluding labor.

\begin{tabular}{lccccc}
\hline Treatments & Seeds & $\begin{array}{c}\text { Fertilizers and } \\
\text { Insecticides }\end{array}$ & Electricity & Total & $\begin{array}{c}\text { Financing } \\
\text { share }\end{array}$ \\
\cline { 2 - 6 } Rainy + SI & 22.73 & 454.55 & 47.73 & 525.01 & 52 \\
Rainy & 22.73 & 454.55 & 0 & 477.27 & 47 \\
Normal + SI & 22.73 & 454.55 & 95.45 & 572.73 & 57 \\
Normal & 22.73 & 454.55 & 0 & 477.27 & 47 \\
Drought + SI & 22.73 & 454.55 & 207.01 & 684.28 & 68 \\
Drought & 22.73 & 454.55 & 0 & 477.27 & 47 \\
Severe drought + SI & 22.73 & 454.55 & 270.83 & 748.11 & 74 \\
Severe drought & 22.73 & 454.55 & 0 & 477.27 & 47 \\
\hline Sl = supplemental irrigation. & & & &
\end{tabular}

interest rate of $3 \%$ per year with no grace period. The amount of bank interest for financing the crop with supplementation ranged from 123.14 to 129.83 USD and was equal to $38.18 \mathrm{USD} \mathrm{ha}^{-1} \mathrm{yr}^{-1}$ for the cultivation without supplemental irrigation.

From the data of costs and gross revenue, the added value was calculated according to the method described by Silva Neto et al. (2009). The added value of the production systems was obtained for 1.0 hectares of production by Eq 1:

$A V=G V P-(F C+V C+D)$

where: AV: Added value in USD; GVP: Gross value of production in USD; FC: fixed costs associated with the production system in USD; VC: variable costs associated with the production system, excluding labor in USD; D: depreciation of equipment and facilities in USD.

A linear relationship ( $\mathrm{AV}=\mathrm{ax}+\mathrm{b}$ ) was used to estimate the added value of 2.0 to 5.0 hectares, with added value on the ordinate axis and agricultural area on the abscissas axis. In the linear model, the marginal contribution per unit of equivalent area is represented by "a" and the fixed capital required for the implementation of the production system is represented by " $b$ ".

The added value obtained for each water scenario was used to estimate the income of farmers, which makes it possible to evaluate the economic viability at the production unit level, according to Eq 2:

$F I=A V-(I+S+T)$

where: $F I$ : farmer's income in USD; $A V$ : added value in USD; $I$ : interest paid to the bank or other financial agent in USD; $S$ : salaries paid to the labor force in USD; $T$ : taxes and tariffs paid to the state in USD.

The value of labor related to soil tillage, sowing, application of pesticides, fertilization and harvesting was estimated at 795.45 USD ha ${ }^{-1} \mathrm{yr}^{-1}$ for both cycles. On the other hand, the land tax was fixed at 1.89 USD ha-1 $\mathrm{yr}^{-1}$ for both cycles.

From Equation 2 it was possible to derive the farmer's income for 1.0 hectares of production. Then, the farmer's income for 2.0 to 5.0 hectares was calculated by constructing a linear model $(\mathrm{FI}=\mathrm{ax}+\mathrm{b})$ that describes the variation of income under the different water scenarios and schemes of supplemental irrigation in relation to the agricultural area per unit of work. In this model, the farmer's income is represented by FI, the marginal contribution of income in relation to the area is represented by "a", and the fixed costs of implementation of the production system by " $b$ ".

An analysis of the level of social reproduction (LSR) of each production unit for agricultural area was performed. LSR is related to the income necessary for social reproduction based on the minimum wage, which was adjusted to 197.92 USD through the Provisional Measure of the Federal Government 919/2020, on 01 Feb 2020. In this case, the LSR value represented in the graph refers to the six-month minimum wage of 1,187.52 USD, considering that in the second half of the year the farmer will engage in other activities to obtain his income. An estimate of the farmer's income was also made for the years 2010 to 2019, a decade marked by enormous losses in the agricultural sector in the Brazilian semi-arid region due to the consecutive years of drought and severe drought.

\section{Results and Discussion}

\section{Maize yield}

In general, the water scenarios with supplemental irrigation with brackish water did not differ statistically in terms of total yield of green ears (Table 3). The only exception was the rainy water scenario, in which the highest mean yield was obtained in the first cycle, which differed from the other treatments. On the other hand, supplemental irrigation in the first year did not cause yield losses in the second year of cultivation, indicating that the salts accumulated in the soil were leached by seasonal rains, a result that is consistent with those obtained in other studies in sub-humid and semi-arid regions (Ayers and Westcot, 1985; Beltrán, 1999; Barbosa et al., 2012; Neves et al., 2015; Terceiro Neto et al., 2013).

For treatments without supplementation there was a decrease in yield for normal treatments in the first cycle and for drought and severe drought treatments in both cycles compared to the rainy scenario (Table 3). The availability of water in the soil in these treatments was not enough to meet the water requirement of the crop, which resulted in low yield. This fact is explained by Taylor et al. (1983), who stated that the low water availability to the plant directly interferes in yield thereby limiting the production of photoassimilates and plant development.

Supplemental irrigation with brackish water increased total yield in normal, drought and severe drought scenarios, compared to treatments without supplementation (Table 3). Normally an excess of salts in the soil or in irrigation water hampers plant growth due to the osmotic and ionic effects of salt stress (Munns and 
Table 3 - Results of $F$ test for total biomass of ears and mean values of total biomass of green maize ears, percentage of commercial yield and percentage of stand reduction, as a function of simulated water scenarios (WS) and supplemental irrigation (SI) with brackish water.

\begin{tabular}{|c|c|c|c|c|}
\hline \multirow{2}{*}{ Year } & \multicolumn{4}{|c|}{$\mathrm{F}$ values (Total biomass of ears) } \\
\hline & WS & $\mathrm{SI}$ & \multicolumn{2}{|c|}{$\mathrm{WS} \times \mathrm{SI}$} \\
\hline 2018 & $20.0^{* *}$ & $61.7^{* *}$ & \multicolumn{2}{|c|}{$2.7^{\mathrm{ns}}$} \\
\hline 2019 & $16.0^{* *}$ & $152.3^{* *}$ & \multicolumn{2}{|c|}{$24.6^{* *}$} \\
\hline \multirow{3}{*}{ Brackish water ( $\left.4.5 \mathrm{dS} \mathrm{m}^{-1}\right)$} & \multicolumn{4}{|c|}{ Simulated water scenarios } \\
\hline & Rainy & Normal & Drought & Severe drought \\
\hline & & $2018\left(\mathrm{~kg} \mathrm{ha}^{-1}\right)$ & & \\
\hline With SI & $\begin{array}{c}14,430.71 \mathrm{Aa}^{1} \\
(100)^{2}\end{array}$ & $\begin{array}{c}11,413.64 \mathrm{Ba} \\
(93.0)\end{array}$ & $\begin{array}{c}10,095.70 \mathrm{Ba} \\
(93.0)\end{array}$ & $\begin{array}{c}9,780.54 \mathrm{Ba} \\
(71.2)\end{array}$ \\
\hline \multirow[t]{2}{*}{ Without SI } & $\begin{array}{c}11,697.57 \mathrm{Aa} \\
(91.3)\end{array}$ & $\begin{array}{c}6,467.50 \mathrm{Bb} \\
(85.9)\end{array}$ & $\begin{array}{c}3,520.88 \mathrm{Cb} \\
(34.0)\end{array}$ & $\begin{array}{c}1,560.20 \mathrm{Db} \\
(5.0)\end{array}$ \\
\hline & \multicolumn{4}{|c|}{$2019\left(\mathrm{~kg} \mathrm{ha}^{-1}\right)$} \\
\hline With SI & $\begin{array}{c}11,735.26 \mathrm{Aa} \\
(100)^{2}\end{array}$ & $\begin{array}{c}11,650.14 \mathrm{Aa} \\
(93.0)\end{array}$ & $\begin{array}{c}10,621.05 \mathrm{Aa} \\
(96.1)\end{array}$ & $\begin{array}{c}9,437.52 \mathrm{Aa} \\
(75.0)\end{array}$ \\
\hline \multirow[t]{2}{*}{ Without SI } & $\begin{array}{c}11,090.09 \mathrm{Aa} \\
(94.3)\end{array}$ & $\begin{array}{c}9,324.14 \mathrm{Ab} \\
(88.5)\end{array}$ & $\begin{array}{c}4,304.93 \mathrm{Bb} \\
(38.0)\end{array}$ & $\begin{array}{c}1,188.00 \mathrm{Cb} \\
(9.0)\end{array}$ \\
\hline & \multicolumn{4}{|c|}{ Mean reduction of final stand (\%) } \\
\hline With SI & $11.5 \pm 3.4^{3}$ & $12.0 \pm 4.2$ & $13.8 \pm 6.0$ & $14.6 \pm 3.6$ \\
\hline Without SI & $11.4 \pm 3.0$ & $26.1 \pm 5.8$ & $37.5 \pm 1.4$ & $67.7 \pm 4.4$ \\
\hline
\end{tabular}

Tester, 2008; Tyagi, 2003). However, in our study brackish water was applied only in dry spells, and low-salinity water used to simulate seasonal rainfall promotes the leaching of salts in the soil profile, reducing the salt concentration in the root zone (Barbosa et al., 2012; Neves et al., 2015). According to Kang et al. (2010), the use of saline water associated with good quality water (rainwater or water of low electrical conductivity) is beneficial to cultivation, since low salinity reduces the accumulation of salts in the root zone, temporarily alleviating the effect of salt stress on plants.

Using brackish water and reusing agricultural drainage water are effective options for reducing the consumption of low-salinity water in irrigation, considering that agriculture is a high water demand sector in Brazil and other countries around the world (Kulkarni, 2011; Murtaza et al., 2006). A number of studies also show that the cyclic use of brackish water is beneficial to crops, especially when low-salinity water is used in the germination and seedling establishment stages (Barbosa et al., 2012; Kaur et al., 2007; Kiani and Mosavata, 2016; Naresh et al., 1993; Sharma et al., 1994; Yadav et al., 2004). It is important to point out that the proposal of using supplemental irrigation with brackish water for rainfed farming in the Brazilian semi-arid region presupposes planting after a rainfall of medium intensity in order to ensure a good plant stand.

The data in Table 3 show reductions in plant stand under the water scenarios evaluated, especially in the treatments without supplemental irrigation. In terms of commercial yield (data used in the economic analysis), there were also higher mean reductions in treatments without supplemental irrigation reaching
64 and $93 \%$ (mean percentages referring to the two years of experiment) in treatments with drought and severe drought, respectively. On the other hand, under supplemental irrigation with brackish water, there was a moderate reduction in commercial yield only in the treatment under severe drought (about $27 \%$ ), indicating the occurrence of moderate salt stress only in this treatment.

The data presented in Table 3 clearly indicate that maize plants were subjected to two types of abiotic constraints: water deficit and salt stress. In treatments without supplemental irrigation, especially under drought and severe drought scenarios, plants were hampered by severe water shortage which limits the stomatal opening, photosynthetic activity, plant growth and yield. On the other hand, salt stress was observed in plants that received supplementation with brackish water for a longer period (supplemental irrigation for plants under severe drought scenarios). In this case, transient salt accumulation in the soil negatively impacts plant physiology and crop yield due to osmotic and ionic effects (Munns and Tester, 2008). Although salt stress is extremely harmful to crops, it was mild compared to water stress, and the use of brackish water as a complement to rainwater should be beneficial to rainfed cultivation in the Brazilian semi-arid region. Similar results have been observed in other regions around the world (Italy - Hamdy et al., 2005; India Chauhan et al., 2008; Iran - Hassanli and Ebrahimian, 2016). However, under severe drought conditions, it is necessary to apply other management strategies to the soil-plant system in order to reduce the losses in the plant stand and the marketable yield with brackish water application. 


\section{Economic analysis}

Figure 3 shows the variation of added value as a function of the agricultural area, making it possible to identify the marginal contribution of the different simulated water scenarios with and without supplemental irrigation. It was observed that water scenarios which received supplementation with brackish water had a higher value of marginal contribution and, consequently, higher added values for each hectare in production. The angle between the lines with and without supplemental irrigation increases considerably from the rainy to the severe drought water scenarios (Figure 3), demonstrating a better result for the water scenarios with supplementation. Soothar et al. (2019) observed a similar result in which irrigation with saline water supplementing rainwater in the vegetative stage of winter wheat proved to be an important alternative to obtaining acceptable yields in areas with scarcity of low-salinity water in Hengshui, China.

The water scenarios without supplemental irrigation did not have fixed costs for implementation and, theoretically, could express better results in economic terms. However, the opposite result was observed because the commercial yields of these treatments were much lower than those observed for plots that received supplemental irrigation (Table 3), resulting in a lower added value for each hectare in production. Hamdy et al. (2005) observed in a study conducted in Italy that the supplemental application of brackish water in wheat and barley cultivation ensures high crop yields with small reductions compared to plantations with low-salinity water.

\section{RAINY}

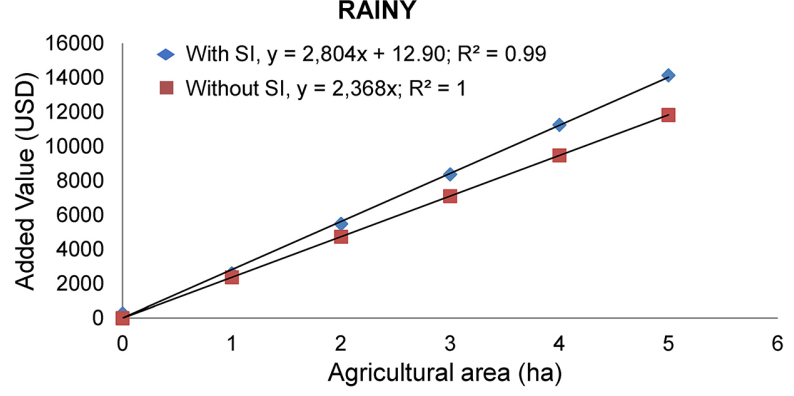

DROUGHT

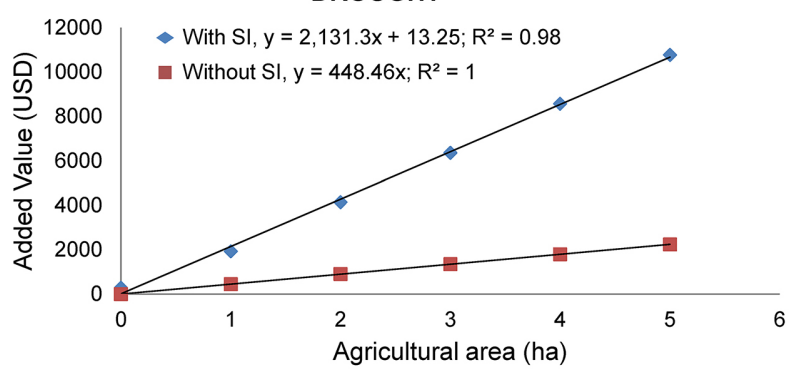

Supplemental irrigation with brackish water, as well as investment in the irrigation system and other strategies, may increase the productivity of maize under rainfed agriculture and, consequently, increase the added value regardless of the water scenario (Figure 3). However, these results may be beneficial mainly for small areas, due to availability or low discharge rates of brackish water sources. Therefore, this proposal may be more applicable to family farming, since this type of enterprise works with small areas and responds more easily to investments with an increase in yield levels.

The added value identifies the wealth obtained from the agricultural production unit, as well as the interactions of technical and economic efficiencies by different means, which is reflected in the production process. From the added value it is possible to measure the income generation capacity of the farm which is an important indicator for comparison of economic results (Silva Neto et al., 2009). However, the high added value, despite being a strong attraction, does not reveal the risk associated with indebtedness.

The farmer's income according to the marginal contribution of each water scenario for an agricultural area of up to 5.0 hectares is shown in Figure 4. For the rainy water scenario approximately 0.8 ha meets the level of social reproduction, that is, from 0.8 ha the cultivation with and without supplementation with brackish water is advantageous for the farmer. The normal water scenario shows that the cultivation of green maize can be advantageous if supplemental irrigation with brackish water is used from 0.9 ha and, if supplementation with brackish water is not adopted, cultivation should be carried out using 1.8 ha to reach the level of social
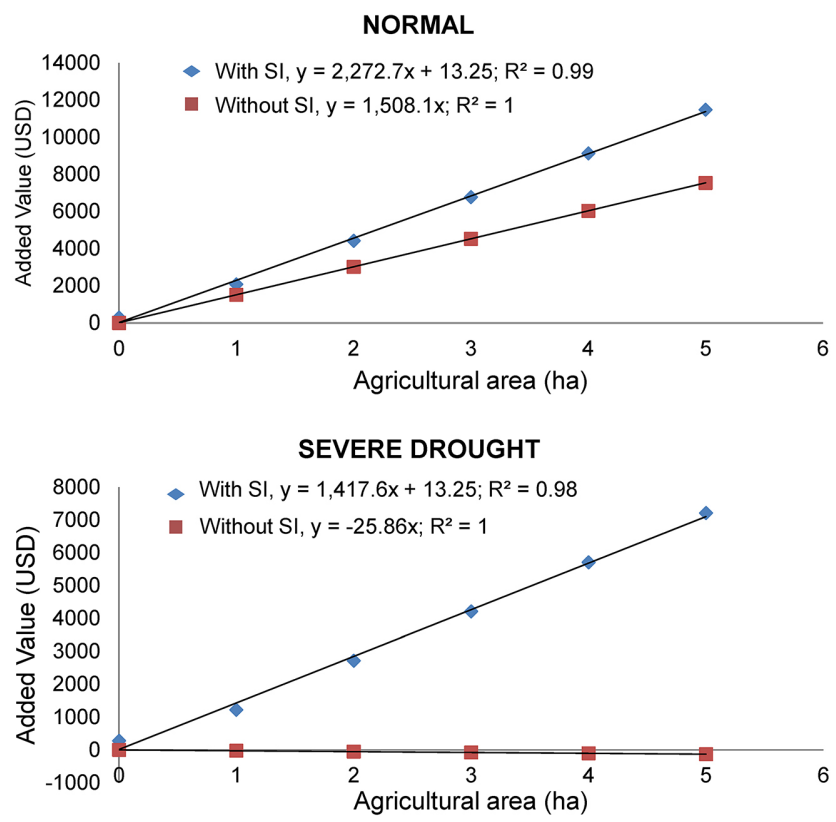

Figure 3 - Added value in the different simulated water scenarios, with and without supplemental irrigation (SI) with brackish water, as a function of the area cultivated with BRS 2022 hybrid maize. 

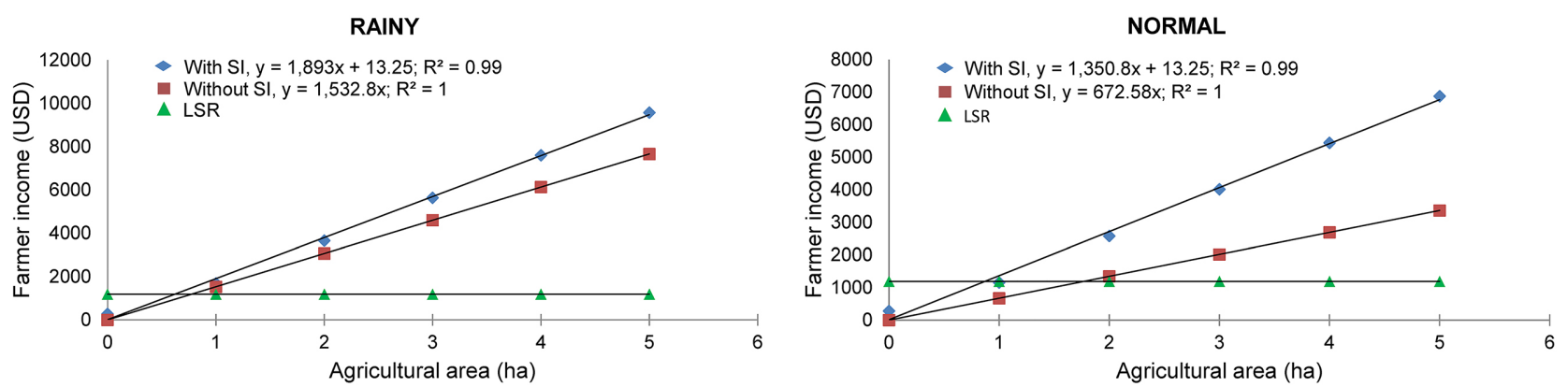

DROUGHT
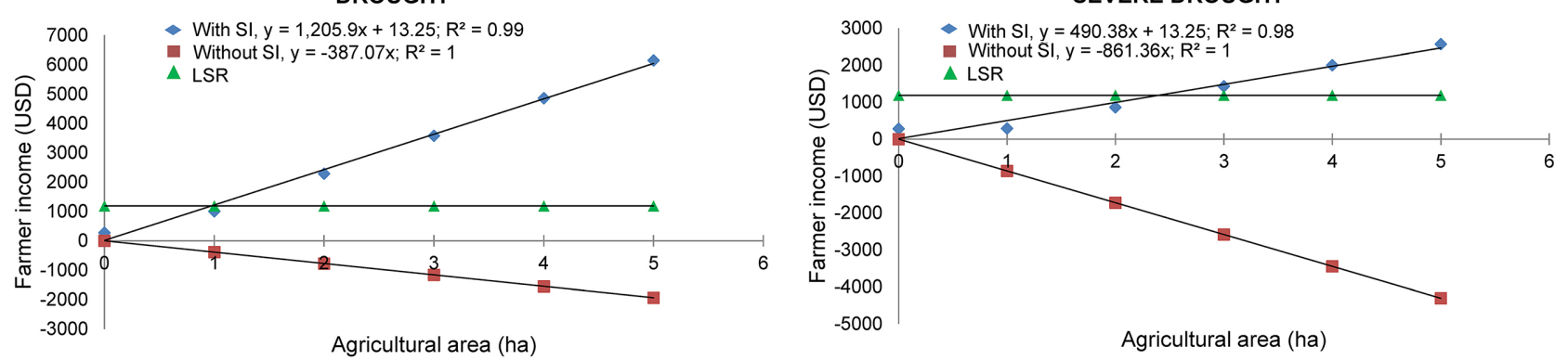

Figure 4 - Farmer's income under the different simulated water scenarios, with and without supplemental irrigation (SI) with brackish water, as a function of the area cultivated with BRS 2022 hybrid maize. LSR = level of social reproduction.

reproduction representing a $100 \%$ increase of the area compared to cultivation with supplemental irrigation.

Under the drought scenario, supplementation with brackish water becomes advantageous from 1.0 ha (Figure 4), while maize cultivation without supplementation is not advantageous because all the values are negative and increase as a function of the area used, that is, the larger the cultivated area, the greater the losses for the farmer. The worst scenario was verified in the severe drought water scenario, where supplemental irrigation with brackish water was advantageous from 2.4 ha, meeting the level of social reproduction, whereas in plots that did not receive supplementation, maize cultivation is not advantageous because all the estimated values are negative. These results confirm the economic viability of supplemental irrigation with brackish water in line with results obtained in other regions of the world (India - Chauhan et al., 2008; Iran - Kiani and Mirlatifi, 2012, Brazil - Terceiro Neto et al., 2013). It is worth pointing out that losses may be lower in cultivation without supplementation, since the plantations are abandoned by farmers after extensive dry spells, partially reducing variable costs, especially those associated with labor. However, farmers' income remains zero or negative resulting in large socioeconomic losses in drought years (Marengo et al., 2017).

Profitability of at least 1.0 minimum wage for the farmer in the rainy, normal and drought water scenarios under supplemental irrigation with brackish water for cultivation from 1.0 ha (Figure 4). For treatments without supplementation, it has been demonstrated that, in general, it is necessary to cultivate large areas or it is infeasible in the years of drought and severe drought. In this context, if the farmer does not have this minimum area for the cultivation of green maize he will not have sufficient income to live throughout the year and this will directly affect the quality of life of his whole family, even with the use of supplemental irrigation. One option would be to diversify the production systems and undertake other non-agricultural activities that can increase family income.

Considering the last decade, 2010-2019, in most of the Brazilian semi-arid region there were three years of drought and four years of severe drought, which resulted in enormous socioeconomic losses (Cunha et al., 2019; Marengo et al., 2017). In this decade total expenditure with the 'Garantia Safra' program of the Federal Government reached approximately 0.9 billion USD, due to successive years of drought. This crop insurance consists of a public policy aimed at family farmers in the Brazilian semi-arid region who have losses equal to or greater than $50 \%$ in the production of various crops, such as cotton, rice, beans, cassava, and maize, or in other agricultural activities of coexistence with the semiarid region caused by drought or excess rainfall.

By applying the data obtained in the present study for the decade 2010-2019 and estimating the farmer's income for each year, it was verified that part of the losses of farmers and the government expenses with the 'Garantia Safra' program could have been reduced by the use of supplemental irrigation with brackish water (Figure 5). The data in Figure 5 reveal enormous losses for farmers who invested in rainfed cultivation in the last decade with at least seven years of negative income. On the other hand, supplementation with brackish water would have been advantageous for all ten years evaluated, resulting in higher yields and higher net income for farmers. 


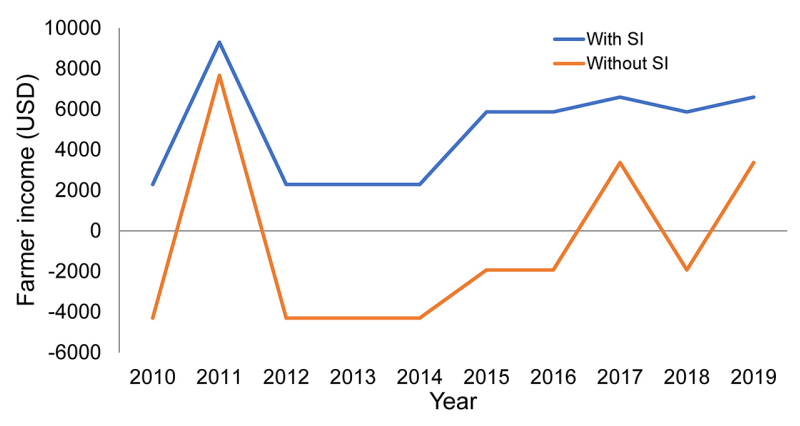

Figure 5 - Estimate of the farmer's income for the period 2010 to 2019 , considering the water scenario of each year with and without supplemental irrigation (SI) with brackish water in the cultivation of BRS 2022 hybrid maize. Rainy (2011), Normal (2017 and 2019), Drought (2015, 2016 and 2018) and Severe Drought (2010, 2012, 2013 and 2014).

This simulation presented in Figure 5 is an indication that in similar situations in the future, supplemental irrigation with brackish water or other sources of marginal water may be an alternative to partially mitigate the negative effects of drought in areas of small farmers of the Brazilian semi-arid region, that can increase crop yields and reduce socioeconomic losses, as observed in other parts of the world (Kiani and Mirlatifi, 2012). However, the data on commercial yield and economic analysis demonstrate the need to use adequate soil and water management strategies, such as using an appropriate leaching fraction or blended water, as well as selecting more tolerant crops, notably when supplemental irrigation with brackish waters is used in years of severe drought. The use of water with lower salinity (between 2.0 and $3.0 \mathrm{dS} \mathrm{m}^{-1}$ ), very common in the Brazilian semi-arid region (Silva Júnior et al., 1999), or which are compatible with the salt tolerance level of the crop, will reduce the negative impacts of salinity on the commercial yield observed in the present study (Table 3). In addition, there is also the need for studies that enable low-cost irrigation systems, which make it possible to reduce fixed costs on equipment and expenses related to electricity, and ensure greater profitability for farmers.

\section{Conclusions}

Mean yields of green maize ears were 13,083, 11,532, 10,358 and $9,609 \mathrm{~kg} \mathrm{ha}^{-1}$ for rainy, normal, drought and severe drought scenarios, as supplemented with brackish water. For the same treatments without supplemental irrigation the yields were 11,394, 7,896, 3,913 and $1,374 \mathrm{~kg} \mathrm{ha}^{-1}$, respectively. Data on added value and farmers' income also showed the economic advantage of this practice of biosaline agriculture, demonstrating that supplemental irrigation is a superior strategy for implementation by small farm holders under rainfed agriculture in the tropical semi-arid region. Under normal, drought and severe drought scenarios, supplementation with brackish water becomes economically advantageous in $0.9,1.0$ and 2.4 ha, respectively, while maize cultivation without supplementation is not advantageous for the last two scenarios. For severe drought conditions, however, supplemental irrigation using brackish water of $\mathrm{ECw}=4.5 \mathrm{dS} \mathrm{m}^{-1}$ reduced commercial yield of green maize ears by about $27 \%$, with negative effects on the farmer's profitability. For this case, it is necessary either to use water with a lower salinity level or select crops of salt tolerance compatible with electrical conductivity of water. Other management strategies of the soil-plant system should also be recommended in order to reduce the losses caused by water salinity in plant stand and marketable yield as well as in soil quality.

\section{Acknowledgments}

Acknowledgments are due to the Brazilian National Council for Scientific and Technological Development (CNPq), 'National Institute of Science and Technology in Salinity (INCTSal)', The Coordination for the Improvement of Higher Level Personnel Agency (CAPES) and the 'Ceará State Development Agency (ADECE)', Brazil, The Cearense Foundation to Support Scientific and Technological Development (FUNCAP), Secretariat for Economic Development and Labor (SEDET) for financial support provided for this research and award of fellowship to the first author (CAPES).

\section{Authors' Contributions}

Conceptualization: Cavalcante, E.S.; Lacerda, C.F.; Costa, R.N.T. Data acquisition: Cavalcante, E.S.; Lacerda, C.F.; Pinho, L.L.; Bezerra, F.M.S.; Oliveira, A.C.; Canjá, J.F. Data analysis: Cavalcante, E.S.; Lacerda, C.F.; Pinho, L.L.; Bezerra, F.M.S.; Oliveira, A.C.; Canjá, J.F. Design of methodology: Cavalcante, E.S.; Lacerda, C.F.; Costa, R.N.T.; Gheyi, H.R. Writing and editing: Cavalcante, E.S.; Lacerda, C.F.; Costa, R.N.T.; Gheyi, H.R.

\section{References}

Allen, R.G.; Pereira, L.S.; Raes, D.; Smith, M. 1998. Crop Evapotranspiration: Guidelines for Computing Crop Water Requirements. FAO, Rome, Italy.

Ayers, R.S.; Westcot, D.W. 1985. Water Quality for Agriculture. FAO: Rome, Italy (FAO Irrigation and Drainage Paper, 29).

Barbosa, F.S.A.; Lacerda, C.F.; Gheyi, H.R.; Farias, G.C.; Silva Junior, R.J.C.; Lage, Y.A.; Hernandez, F.F.F. 2012. Yield and ion content in maize irrigated with saline water in a continuous or alternating system. Ciência Rural 42: 1731-1737. https://doi. org/10.1590/S0103-84782012001000003

Beltrán, J.M. 1999. Irrigation with saline water: benefits and environmental impact. Agricultural Water Management 40: 183194. https://doi.org/10.1016/S0378-3774(98)00120-6

Chauhan, C.P.S.; Singh, R.B.; Gupta, S.K. 2008. Supplemental irrigation of wheat with saline water. Agricultural Water Management 95: 253-258. https://doi.org/10.1016/j.agwat.2007.10.007 
Cunha, A.P.M.A.; Zeri, M.; Deusdará Leal, K.; Costa, L.; Cuartas, L.A.; Marengo, J.A.; Tomasella, J.; Vieira, R.M.; Barbosa, A.A.; Cunningham, C.; Cal Garcia, J.V.; Broedel, E.; Alvalá, R.; RibeiroNeto, G. 2019. Extreme drought events over Brazil from 2011 to 2019. Atmosphere 10: 642. https://doi.org/10.3390/atmos10110642

Food and Agriculture Organization [FAO]. Land use indicators. 2017. Available at: http://www.fao.org/faostat/en/\#data/EL/ visualize [Accessed Mar 20, 2020]

Hamdy, A.; Sardob, V.; Ghanem, K.A.F. 2005. Saline water in supplemental irrigation of wheat and barley under rainfed agriculture. Agricultural Water Management 78: 122-127. https://doi.org/10.1016/j.agwat.2005.04.017

Hassanli, M.; Ebrahimian, H. 2016. Cyclic use of saline and nonsaline water to increase water use efficiency and soil sustainability on drip irrigated maize. Spanish Journal of Agricultural Research 14: 15. http://dx.doi.org/10.5424/sjar/2016144-9238

Kang, Y.; Chen, M.; Wan, S. 2010. Effects of drip irrigation with saline water on waxy maize (Zea mays L. var.ceratina Kulesh) in north China Plain. Agricultural Water Management 97: 13031309. https://doi.org/10.1016/j.agwat.2010.03.006

Kaur, R.; Paul, M.; Malik, R. 2007. Impact assessment and recommendation of alternative conjunctive water use strategies for salt affected agricultural lands through a field scale decision support system: a case study. Environmental Monitoring and Assessment 129: 257-270. https://doi.org/10.1007/s10661-006-9359-6

Kiani, A.R.; Mirlatifi, S.M. 2012. Effect of different quantities of supplemental irrigation and its salinity on yield and water use of winter wheat (Triticum aestivum). Irrigation and Drainage 61: 89-98. https://doi.org/10.1002/ird.629

Kiani, A.R.; Mosavata, A. 2016. Effect of different alternate irrigation strategies using saline and non-saline water on corn yield, salinity and moisture distribution in soil profile. Journal of Water and Soil 30: 1595-1606. https://doi.org/10.22067/jsw.v0i0.41857

Kulkarni, S. 2011. Innovative technologies for water saving in irrigated agriculture. International Journal of Water Resources and Arid Environments 1: 226-231. Available at: https:// www.researchgate.net/publication/229050067_Innovative_ Technologies_for__ Water_Saving_in_Irrigated_Agriculture [Accessed 22 Jan 2020]

Marengo, J.A.; Torres, R.R.; Alves, L.M. 2017. Drought in northeast Brazil: past, present, and future. Theoretical and Applied Climatology 129: 1189-1200.

Menezes, H.E.A.; Brito, J.I.B.; Lima, R.A.F.A. 2010. Dry spell and agricultural production in the State of Paraíba, Brazil. Revista Brasileira de Engenharia Agrícola Ambiental 14: 181-186 (in Portuguese, with abstract in English). https://doi.org/10.1590/ S1415-43662010000200009

Munns, R.; Tester, M. 2008. Mechanisms of salinity tolerance. Annual Review of Plant Biology 59: 651-681. https://doi. org/10.1146/annurev.arplant.59.032607.092911

Murtaza, G.; Ghafoor, A.; Qadir, M. 2006. Irrigation and soil management strategies for using saline-sodic water in a cottonwheat rotation. Agricultural Water Management 81: 98-114.

Naresh, R.K.; Minhas, P.S.; Goyal, A.K.; Chauhan, C.P.S.; Gupta, R.K. 1993. Conjunctive use of saline and non-saline waters. II. Field comparisons of cyclic uses and mixing for wheat. Agricultural Water Management 23: 139-148. https://doi. org/10.1016/0378-3774|(93)90037-B
Neves, A.L.R.; Lacerda, C.F.; Sousa, C.H.C.; Silva, F.L.B.; Gheyi, H.R.; Ferreira, F.J.; Andrade Filho, F.L. 2015. Growth and yield of cowpea/sunflower crop rotation under different irrigation management strategies with saline water. Ciência Rural 45: 814820. https://doi.org/10.1590/0103-8478cr20131657

Oster, J.; Grattan, S. 2002. Drainage water reuse. Irrigation and Drainage Systems 16: 297-310. https://doi.org.ez11.periodicos. capes.gov.br/10.1023/A:1024859729505

Pessoa, L.G.M.; Freire, M.B.G.S.; Santos, R.; Freire, F.J.; Miranda, M.F.A.; Santos, P.R. 2019. Saline water irrigation in semiarid region. I. Effects on soil chemical properties. Australian Journal of Crop Science 13: 1169-1176. https://doi.org/10.21475/ ajcs.19.13.07.p1686

Sharma, D.P.; Rao, K.V.G.K.; Singh, K.N.; Kumbhare, P.S.; Oosterbaan, R.J. 1994. Conjunctive use of saline and non-saline irrigation waters in semi-arid regions. Irrigation Science 15: 2533. https://doi.org/10.1007/BF00187792

Silva Júnior, L.G.A.; Gheyi, H.R.; Medeiros, J.F. 1999. Chemical composition of water in the crystalline region of northeast Brazil. Revista Brasileira de Engenharia Agrícola Ambiental 3: 11-17 (in Portuguese, with abstract in English). https://doi. org/10.1590/1807-1929/agriambi.v3n1p11-17

Silva Neto, B.; Dezen, M.; Santos, P.E. 2009. The concept of social reproduction in the analysis of units of agricultural production. Teoria e Evidência Econômica 32: 87-108 (in Portuguese, with abstract in English). Available at: http://seer.upf.br/index.php/ rtee/article/view/ 4747/3181 [Accessed Feb 30, 2020]

Soothar, R.K.; Zhang, W.; Zhang, Y.; Tankari, M.; Mirjat, U.; Wang, Y. 2019. Evaluating the performance of SALTMED model under alternate irrigation using saline and fresh water strategies to winter wheat in the north China Plain. Environmental Science and Pollution Research 26: 34499-34509. https://doi.org/10.1007/ s11356-019-06540-w.

Taylor, H.M.; Jordan, W.R.; Sinclair, T.R. 1983. Limitations to efficient water use and crop production. ASA/CSSA/SSSA, Madison, WI, USA.

Terceiro Neto, C.P.C.; Gheyi, H.R.; Medeiros, J.F.; Dias, N.S.; Campos, M.S. 2013. Productivity and quality of melon under management with increasing salinity water. Pesquisa Agropecuária Tropical 43: 354-362 (in Portuguese, with abstract in English).

Tyagi, N.K. 2003. Managing saline and alkali water for higher productivity. p. 65-75. In: Kijne, J.; Molden, D.J.; Barker, R., eds. Water productivity in agriculture: limits and opportunities for improvement. CABI, Wallingford, England. http://dx.doi. org/10.1079/9780851996691.0069

Yadav, R.; Kumar, A.; Lal, D.; Batra, L. 2004. Yield responses of winter (rabi) forage crops to irrigation with saline drainage water. Experimental Agriculture 40: 65-75. https://doi.org/10.1017/ S0014479703001431

Zaninelli, P.G.; Menéndez, D.G.; Falco, M.; Franca, N.L.; Carril, A.F. 2019. Future hydroclimatological changes in South America based on an ensemble of regional climate models. Climate Dynamics 52: 819-830. https://doi.org/10.1007/s00382-018-4225-0 